\title{
Climatological Analysis of Aerosols Optical Properties by Airborne Sensors and in Situ Measurements in West Africa: Case of the Sahelian Zone
}

\author{
Nébon Bado ${ }^{1,2 *}$, Adama Ouédraogo ${ }^{1,3}$, Hassime Guengané1, Thierry Sikoudouin Maurice Ky ${ }^{1}$, \\ Serge Dimitri Bazyomo',4, Bruno Korgo', Mamadou Simina Dramé2, Saidou Moustapha Sall², \\ Florent P. Kieno' ${ }^{1}$ Dieudonné Joseph Bathiebo' ${ }^{1}$
}

\author{
${ }^{1}$ Laboratoire d'Energies Thermiques Renouvelables (L.E.T.RE), Université Joseph Ki Zerbo, Ouaga, Burkina Faso \\ ${ }^{2}$ Laboratoire de Physique de l'Atmosphère et de l'Océan Siméon Fongang, Université Cheikh Anta Diop, Dakar-Fann, Sénégal \\ ${ }^{3}$ Centre Universitaire Polytechnique de Kaya (CUP-K), Kaya, Burkina Faso \\ ${ }^{4}$ Institute of Mathematics and Physical Sciences, University of Abomey-Calavi, Porto-Novo, Benin \\ Email: *nebonbado@gmail.com
}

How to cite this paper: Bado, N., Ouédraogo, A., Guengané, H., Ky, T.S.M., Bazyomo, S.D., Korgo, B., Dramé, M.S., Sall, S.M., Kieno, F.P. and Bathiebo, D.J. (2019) Climatological Analysis of Aerosols Optical Properties by Airborne Sensors and in Situ Measurements in West Africa: Case of the Sahelian Zone. Open Journal of Air Pollution, 8, 118-135. https://doi.org/10.4236/ojap.2019.84007

Received: September 26, 2019 Accepted: December 1, 2019

Published: December 4, 2019

Copyright $\odot 2019$ by author(s) and Scientific Research Publishing Inc. This work is licensed under the Creative Commons Attribution International License (CC BY 4.0).

http://creativecommons.org/licenses/by/4.0/

\begin{abstract}
This paper deals with the climatology of aerosols in West Africa based on satellite and in situ measurements between 2001 and 2016 and covers four sites in the Sahelian zone. There are indeed Banizoumbou $\left(13.541^{\circ} \mathrm{N}, 02.665^{\circ} \mathrm{E}\right)$, Cinzana $\left(13.278^{\circ} \mathrm{N}, 05.934^{\circ} \mathrm{W}\right)$, Dakar $\left(14.394^{\circ} \mathrm{N}, 16.959^{\circ} \mathrm{W}\right)$ and Ouagadougou $\left(12.20^{\circ} \mathrm{N}, 1.40^{\circ} \mathrm{W}\right)$ located respectively in Niger, Mali, Senegal and Burkina Faso. Thus, an intercomparison between the satellite observations and the in situ measurements shows a good correlation between MODIS and AERONET with a correlation coefficient $\mathrm{R}=0.86$ at Cinzana, $\mathrm{R}=0.85$ at Banizounbou, $\mathrm{R}=0.84$ at Ouagadougou and a low correlation coefficient $\mathrm{R}=$ 0.66 calculated on the Dakar site. Like MODIS, SeaWiFS shows a very good correspondence with measurements of the ground photometer especially for Banizoumbou $(\mathrm{R}=0.89)$, Cinzana $(\mathrm{R}=0.88)$ and Dakar $(\mathrm{R}=0.75)$ followed by a low correlation coefficient calculated on the Ouagadougou site $(R=0.64)$. The performance of these airborne sensors is also corroborated by the calculation of root mean square error (RMSE) and the mean absolute error (MAE). Following this validation, a climatological analysis based on aerosol optical depth (AOD) shows the seasonality of aerosols in West Africa strongly influenced by the climate dynamics illustrated by the MERRA model reanalysis. This seasonal spatial distribution of aerosols justifies the temporal variability of the particles observed at the different sites in the Sahel. In addition, a combined analysis of AOD and Angstrom coefficient indicates the aerosol period
\end{abstract}


in the Sahel in spring (March-April-May) and summer (June-July-August). However, these aerosols are strongly dominated by desert dust whose main sources are located north in the Sahara and Sahel.

\section{Keywords}

West-Africa, Aerosols, Airborne Sensors, Aeronet, MERRA Model

\section{Introduction}

The term "aerosol" was invented to describe all solid or liquid particles suspended in the atmosphere with the exception of water droplets and ice crystals constituting the clouds [1]. These particles are of natural origin strongly dominated by primary particles such as desert dust, sea salts that are emitted directly into the atmosphere and of anthropogenic origin related to the action of man through industrial emissions, bushfires and agricultural practices [2]. On the African continent, West Africa is one of the main areas of high potential in terms of dust sources and combustion in the world [1] [3]. Following this, dust clouds contained in the Saharan air layer spread evenly throughout the continent and to the ocean, especially during the winter period [4] [5]. These desert dusts have a strong influence on the radiation balance, the climate and also affect the hydraulic cycle [6] [7] [8]. In addition, an analysis of the in situ measurements of the AERONET network carried out by Dramé et al. [9] allows to locateaerosol maxima in West Africa in spring (March-April-May) and in summer (June-July-August) whose emission sources are located in the Sahara [7]. At these times of the year, large Aerosol Optical Depth (AOD) values associated with a frequency of dust events are measured at several stations of the AERONET network in the Sahel [1] [9]. To this end, a dust event initiated on July 03, 2010 from the Sahara desert in southern Algeria following a strong thermal depression, and caused an increase in AOD with daily average values ranging from 3.5 to 4 measured on the station of Dakar in Senegal on July 07, 2010 [5]. In addition, a study conducted by Senghor et al. [10] showed a strong seasonal variability of the dust layer in the West African zone. This makes it possible to locate the aerosols around $3 \mathrm{~km}$ of altitude in spring and between 3 and $5 \mathrm{~km}$ during summer. However, in winter the dust is more observed at the surface below $2 \mathrm{~km} \mathrm{[5]} \mathrm{[10],} \mathrm{which} \mathrm{is} \mathrm{at} \mathrm{the} \mathrm{origin}$ of the numerous cases of diseases linked to the respiratory system and the meningitis epidemics observed during the harmattan which is a warm and dry north-easterly wind predominant during the autumn (September-October-November), winter (December-January-February) and spring in the Sahel [11] [12] [13] [14]. This distribution of particles is also in agreement with their radiative impact noted on the surface, in the atmosphere and at the top of the atmosphere [15]. In the Sahel, atmospheric particles are strongly dominated by desert dusts characterized by their scattering and absorption properties of solar radiation. This characterizes their impact in the climate system thus causing the warming 
or cooling of the atmosphere. Indeed, aerosols have a dual role on the climate and the environment because of their optical and microphysical properties that vary according to the emission sources, the chemical nature and the mode of formation. This justifies the complexity of their study, making them particles that are still very poorly understood. To better understand the role of these particles in the climate system, several international efforts have been devoted to their study and the understanding of their interactions with other components of the global climate system. These studies, which include measurement campaigns and monitoring networks, make it possible to characterize the physicochemical properties of these particles and to evaluate their impact on the climate. Despite all these studies, the climatic role of aerosols is still known with large uncertainties [16]. It is in this context that this work and our interest in atmospheric aerosols, whose objective is to contribute to an aerosol optical characterization in West Africa, based on satellite observations and in situ measurements of the AERONET network and also from the MERRA model reanalysis. This allows us to make an intra-seasonal and interannual climatology of aerosols in the sub-region through their optical properties and to show their variability in time and space between 2001 and 2016.

\section{Materials and Data}

\subsection{AERONET Network (Aerosol Robotic NETwork)}

For a better characterization of particles on the planet, a network of CIMEL photometers is developed all over the globe: the global AERONET network initially established by NASA (National Aeronautics and Space Administration) in collaboration with the Laboratory of Atmospheric Optics (LOA) of the National Center for Scientific Research (CNRS). This network enables archiving and getting public access to data on the optical, microphysical and radiative properties of aerosols in an almost real-time, continuously and for the long-term [17]. These are inversion results of various algorithms elaborated and improved over time by Dubovik et al. [18] [19] [20] [21]. AERONET aims at characterizing aerosol properties by constituting a permanently available database for aerosol climatology and the validation of satellite observations [22]. In addition, AERONET consists of partner networks such as PHOTONS (Operational Processing Photometry for Satellite Normalization) which deals with all photometers installed on the African and European continents.

\subsection{MODIS (MODerate Resolution Imaging Spectro-Radiometer)}

MODIS is a sensor transported by the TERRA satellites since December 1999 and Aqua in April 2002. TERRA sweeps the earth surface from the North to the South around the equator in the morning around 10:30 am while Aqua occurs in the evening, around 10:30 am in an orbit oriented South-North of the equator [23]. MODIS has 36 spectral bands that enable it to provide measurements on the atmosphere, the earth and the ocean, 7 of which are used to study aerosols 
$(466,553,644,855,1243,1632$ and $2119 \mathrm{~nm})$. In addition, it uses different algorithms to invert aerosol properties on earth [24] and on seas [25] where measurements are made with a spatial resolution ranging from 1 to $250 \mathrm{~km}$ and temporal from 1 to 2 days. For our study, we use MODIS-Terra Deep-Blue inversions at $550 \mathrm{~nm}$ and available on NASA's Giovanni site (https://giovanni.gsfc.nasa.gov/giovanni/). Indeed, the Deep Blue algorithm takes into account cloud masks, the aerosol model and the reflection of shiny surfaces [23] [26]. This makes it possible to eliminate contaminations due to the reflection of the shiny surfaces and to improve the qualified observations in level 2 in areas like the desert of the Sahara, the arid, semi-arid and urban regions where reflectivity is very significant [27].

\subsection{SeaWiFS (Sea-Viewing Wide Field-of-View Sensor)}

SeaWiFS is a sensor of the NASA observation system developed to study ocean color [10]. However, it makes measurements on the optical properties of aerosols, in particular the optical thickness and the Angström coefficient. In orbit since September 1997, SeaWiFS continues to perform measurements with very good sensor performance in different wavelengths (412, 443, 490, 510, 555, 670 and $865 \mathrm{~nm}$ ) where the Angström coefficient is calculated in the spectral range 510 to $865 \mathrm{~nm}$. In addition, aerosol products supplied by SeaWiFS are mainly applicable and valid for oceanic regions [28] [29] and are available on NASA's website (https://giovanni.gsfc.nasa.gov/giovanni/). But, according to Senghor et al. [10] SeaWiFS can be adapted and applied to the study of aerosols in some areas of the Sahel because of its very good correlation. Moreover, SeaWiFS has a threshold reflectivity at $865 \mathrm{~nm}$ corresponding to 0.3 in AOD above which aerosol inversions are limited [28].

\subsection{Modern-Era Retrospective Analysis for Research and Applications (MERRA)}

In this work, we use wind data at $10 \mathrm{~m}$ altitude derived from MERRA model reanalysis. Indeed, these reanalysis are based on satellite observations from NASA and are available from 1979 to the present days. The model was initiated by NASA and is especially suitable for climatic analysis whose data are available continuously and then in the long-term on NASA's Giovanni site.

\subsection{Data Validation Methodology}

We are carrying out a validation of the MODIS sensor measurements on board of the TERRA satellite and those of the SeaWiFS satellite with the AERONET inversions at a wavelength of $550 \mathrm{~nm}$. This makes it possible to determine the satellite model that best corresponds to the study and the adequate monitoring of atmospheric particles in the sub-region, particularly the Sahel. For this, the measurement period concerned by this validation depends on the availability of AERONET and airborne sensors data. In addition, an interpolation is made in the spectral range of $440 \mathrm{~nm}$ and $870 \mathrm{~nm}$ to calculate $\mathrm{AOD}_{\mathrm{AERONET}}$ at $550 \mathrm{~nm}$ 
based on photometric measurements at $675 \mathrm{~nm}$ according to Equation (1) [30] [31] [32] [33].

$$
\operatorname{AOD}_{a}=\operatorname{AOD}_{b}\left(\frac{a}{b}\right)^{-\alpha}
$$

In this equation, a and $b$ denote wavelengths, $\alpha$ the Angström coefficient calculated between $440 \mathrm{~nm}$ and $870 \mathrm{~nm}, \mathrm{AOD}_{a}$ and $\mathrm{AOD}_{b}$ aerosols optical depth respectively at wavelengths $a$ and $b$. The Aerosol Optical Depth (AOD) which depends on the wavelength $\lambda$ and the attenuation coefficient $\alpha_{\text {ext }}(\lambda, z)$ is given by Equation (2).

$$
\mathrm{AOD}=\int_{\Delta z} \alpha_{e x t}(\lambda, z) \mathrm{d} z
$$

Moreover, an analysis of the linear regression is made on the basis of the relation 3 where $m$ is the slope and $C$ the intercept [34]. This makes it possible to correlate observations with ground measurements. Furthermore, parameters $m$ and $C$ give information on the local and spatial characteristics of aerosols, namely the correspondence between the aerosol model considered in the inversion algorithm and the aerosol layer probed [35].

$$
\mathrm{AOD}_{\text {Sat }}=m \cdot \mathrm{AOD}_{\text {AERONET }}+C
$$

We also calculate the mean square error (RMSE) and the mean absolute error (MAE) given by Equation (4) and Equation (5) where $n$ represents the number of measurements [34] [36].

$$
\begin{gathered}
\mathrm{RMSE}=\left[\frac{1}{n} \sum_{i=1}^{n}\left(\mathrm{AOD}_{\text {Satellite }_{i}}-\mathrm{AOD}_{\text {AERONET }_{i}}\right)^{2}\right]^{1 / 2} \\
\mathrm{MAE}=\frac{1}{n} \sum_{i=1}^{n}\left|\mathrm{AOD}_{\text {satellite }_{i}}-\mathrm{AOD}_{\text {AERONET }_{i}}\right|
\end{gathered}
$$

These calculations show the relative errors in the satellite data that can justify measurement differences between satellite and AERONET. Moreover, RMSE and MAE are as close to zero as the two series of measurements are similar.

\subsection{Presentation and Geographical Location of the Study Sites}

This study focuses on four sites in the latitude band between $12^{\circ} \mathrm{N}$ and $16^{\circ} \mathrm{N}$. The choice of these sites is mainly based on the availability of AERONET measurements and our interest in the study of atmospheric aerosols in the Sahel and West Africa which is one of the main areas of high potential in terms of dust sources and combustion in the world [1] [2]. Each site is located in the West African zone then identified by its geographical coordinates indicated in blue dot in Figure 1. These are actually the Banizoumbou site $\left(13.541^{\circ} \mathrm{N}, 02.665^{\circ} \mathrm{E}\right)$ located $50 \mathrm{~km}$ from Niamey in Niger, Cinzana $\left(13.278^{\circ} \mathrm{N}, 05.934^{\circ} \mathrm{W}\right)$ in Mali, Dakar $\left(14.394^{\circ} \mathrm{N}, 16.959^{\circ} \mathrm{W}\right)$ located in Senegal and Ouagadougou $\left(12.20^{\circ} \mathrm{N}\right.$, $\left.1.40^{\circ} \mathrm{W}\right)$ in Burkina Faso. These sites are all subject to the same harmattan and West African monsoon flow regime. Unlike the harmattan flow, which is a northeastern continental wind, the monsoon is a southwest wind of oceanic origin 


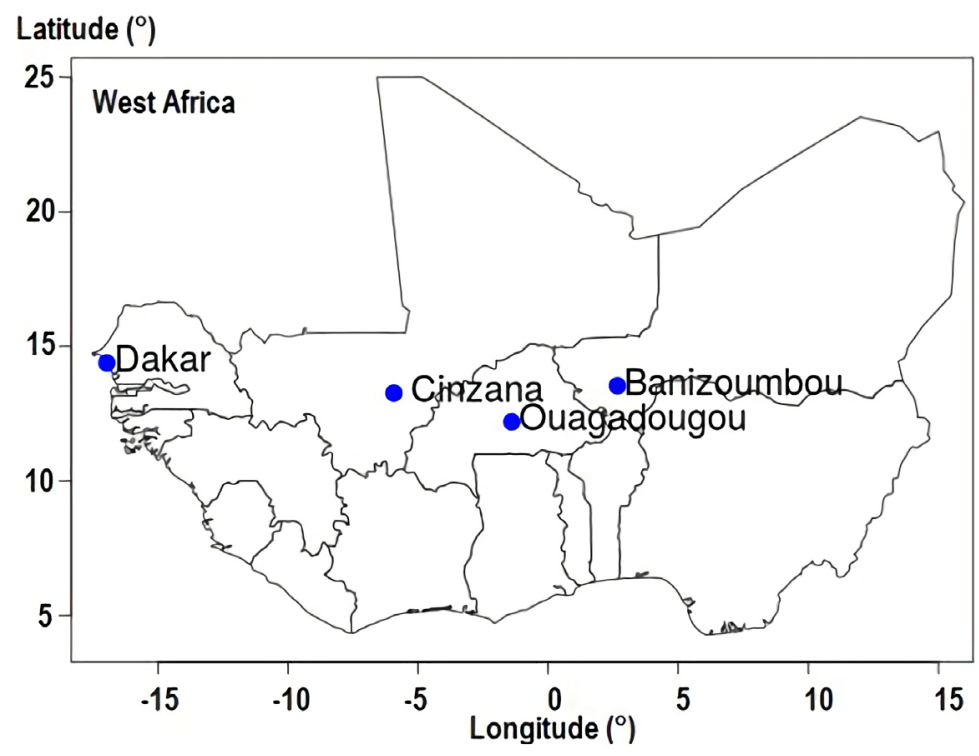

Figure 1. Map of AERONET stations used in this study.

and responsible for cloud convection. This airflow (monsoon) is more predominant in the summer period between June and August in West Africa.

\section{Results and Discussion}

\subsection{Validation of Satellite Inversion Codes by Measurements in Situ}

The representation of the linear regression shows the correlation between the MODIS and AERONET sensors illustrated by the graphs in Figure 2. This indicates a better correlation between the MODIS and ERONET measured values with a regression coefficient $\mathrm{R}=0.86$ at Cinzana (Figure 2(b)), $\mathrm{R}=0.85$ at Banizounbou (Figure 2(a)), $\mathrm{R}=0.84$ at Ouagadougou (Figure 2(d)) with a weak correlation coefficient $\mathrm{R}=0.66$ calculated on the Dakar site (Figure $2(\mathrm{c})$ ). This shows the good correlation of MODIS at ground level with respect to the oceanic because of the variability of the surface and contamination of the MODIS signal by water particles [33] [34] [35]. Thus, the weak correlation with Dakar could be related to the influence of the ocean. In addition, MODIS has linear regression with slopes $(\mathrm{m})$ ranging from 0.63 to 0.89 and low values of the intercept $(C)$ between 0.02 and 0.14 .

Like MODIS, SeaWiFS shows a very good correspondence with the in-situ measurements of the ground photometer especially for Banizoumbou $(\mathrm{R}=0.89)$, Cinzana $(\mathrm{R}=0.88)$ and Dakar $(\mathrm{R}=0.75)$ marked by relatively high correlation coefficients (Figure 3 ).These different correlations are clearly illustrated by the slopes of the linear regression which are $0.93,0.80$ and 0.75 with almost zero points of intercept and associated with values of $0.01,0.08$ and 0.09 , notably at Banizoumbou (Figure 3(a)), Cinzana (Figure 3(b)) and Dakar (Figure 3(c)) respectively. But SeaWiFS proves less representative for the Ouagadougou site $(\mathrm{R}=0.64)$ with a slope $(\mathrm{m})$ corresponding to 0.48 and a value of the intercept 

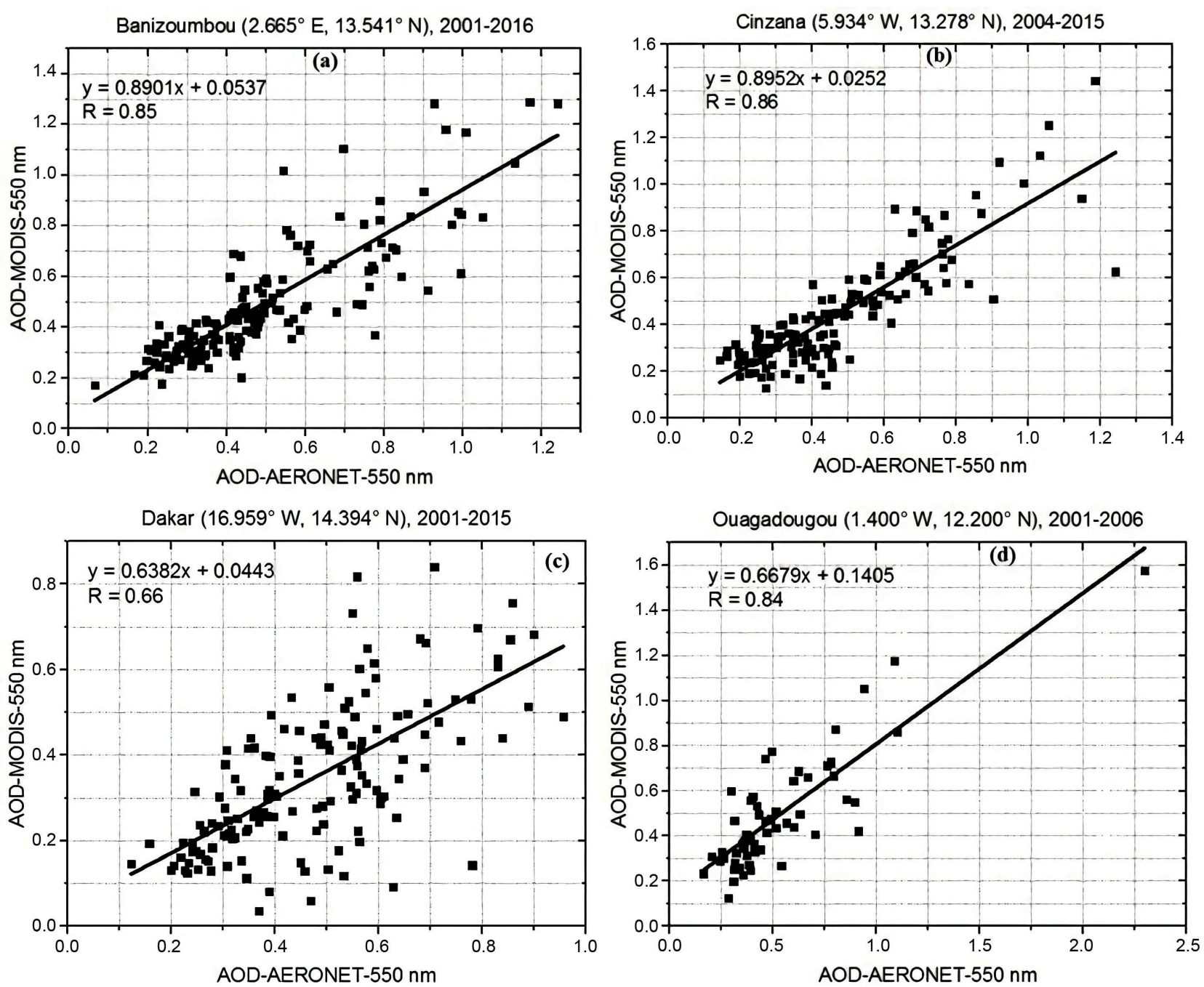

Figure 2. Comparison of monthly mean aerosol optical depth (AOD) between MODIS and ground measurements from AERONET network at Banizoumbou (2001-2016), Cinzana (2004-2015), Dakar (2001-2015) and Ouagadougou (2001-2006).

(C) recorded at 0.17 (Figure 3(d)), which is a sign of important errors that could affect the observations justifying the weak correlation.

\subsection{Validation of Observations by Calculating RMSE and MAE}

The RMSE and MAE values calculated for the different sensors are relatively low especially with the MODIS sensor where these errors vary between 0.12 to 0.18 and 0.09 to 0.14 respectively (Table 1 ). However, the maximum errors obtained by MODIS are calculated on the Dakar site $(\mathrm{RMSE}=0.18$ and $\mathrm{MAE}=0.14)$. This is in agreement with the correlation coefficient $(\mathrm{R}=0.66)$ calculated on this site. As for SeaWiFS, the maximum values of RMSE and MAE are observed on the Ouagadougou site (RMSE $=0.27$ and $\mathrm{MAE}=0.20$ ) justifying the weak correlation between SeaWiFS and AERONET $(\mathrm{R}=0.64)$. This further confirms the SeaWiFS limits in some areas probably due to the nature of the aerosols probes compared to that of the particles embedded in the airborne sensor inversion algorithm. 

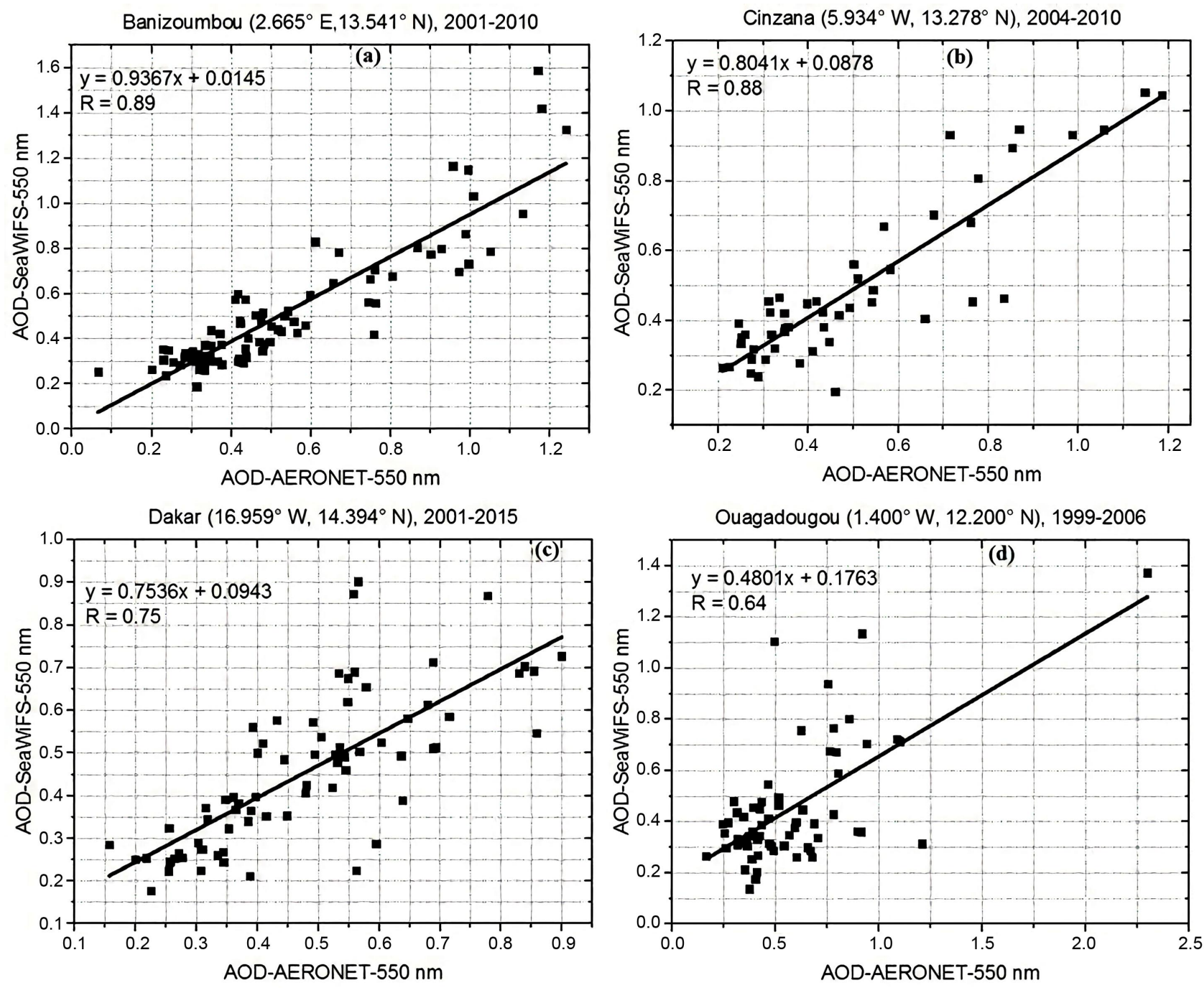

Figure 3. Comparison of monthly mean aerosol optical depth (AOD) between SeaWiFS and ground measurements from AERONET network at Banizoumbou (2001-2010), Cinzana (2004-2010), Dakar (2001-2015) and Ouagadougou (1999-2006).

Table 1. Illustration of errors by calculating RMSE (mean square error) and MAE (mean absolute error).

\begin{tabular}{ccccc}
\hline \multirow{2}{*}{ Sites } & \multicolumn{2}{c}{ MODIS } & \multicolumn{2}{c}{ SeaWiFS } \\
\cline { 2 - 5 } & RMSE & MAE & RMSE & MAE \\
\hline Banizoumbou & 0.13 & 0.09 & 0.12 & 0.09 \\
Cinzana & 0.12 & 0.09 & 0.11 & 0.08 \\
Dakar & 0.18 & 0.14 & 0.12 & 0.09 \\
Ouagadougou & 0.17 & 0.12 & 0.27 & 0.20 \\
\hline
\end{tabular}

\subsection{Spatial Variability of Aerosols in West Africa}

In order to be able to locate the aerosols in time and space in West Africa, an intra-seasonal representation is made on the basis of the visualization of the MODIS-Terra sensor at $550 \mathrm{~nm}$ between 2001 and 2016. To this, are added Fig- 
ure 4 and Figure 5 which respectively represent the seasonality and time series of the wind speed intensities at $10 \mathrm{~m}$ altitude over the same period according to the MERRA model. Indeed, wind is a key parameter in the uplift, transport and deposition of aerosols and defines the dynamics of the atmosphere that controls the life cycle of atmospheric particles [37].

An analysis of Figure 4 shows the aerosol maxima in spring (MAM), period of dust in West African region [16] [38] and also in autumn during the period of September to November (SON). In spring (Figure 4(b)), aerosol maxima are observed on the eastern side of Niger probably due to the depression of Bodélé in Chad related to the thermal depression because of the strong sunshine during this period especially in the north. Then, the particles are distributed throughout the West African zone in accordance with the harmattan flow regime, in particular in its part below $20^{\circ} \mathrm{N}$. This same period (MAM) is characterized by minima in wind speed (Figure 6) but is rather marked by a strong sunshine especially in the Sahel and the Sahara. This solar downward radiation is causing an increase of the temperature at the surface and in the lower layers. For this reason, the pressure gradient induced by the digging of the thermal depression is very important, justifying the wind maxima in the east of Niger and the north-west of Mali (Figure 5(b)). This phenomenon is responsible for intense emissions of desert dust at the level of dust sources in the north and remarkable atmospheric circulation in March-April-May (MAM).
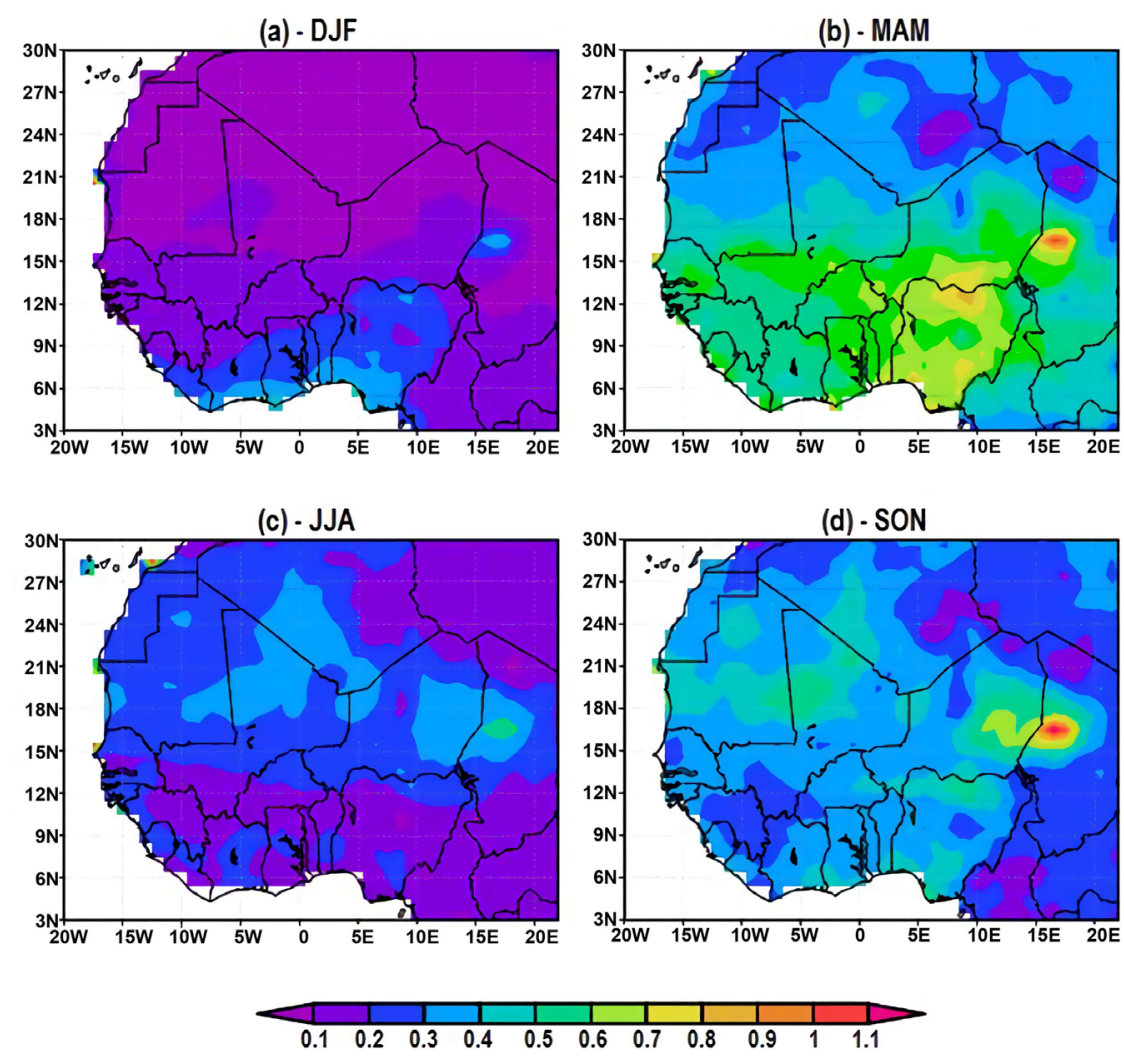

Figure 4. MODIS seasonal (DJF, MAM, JJA and SON) aerosol optical depth (550 nm) averaged between 2001 and 2016 over West Africa. 

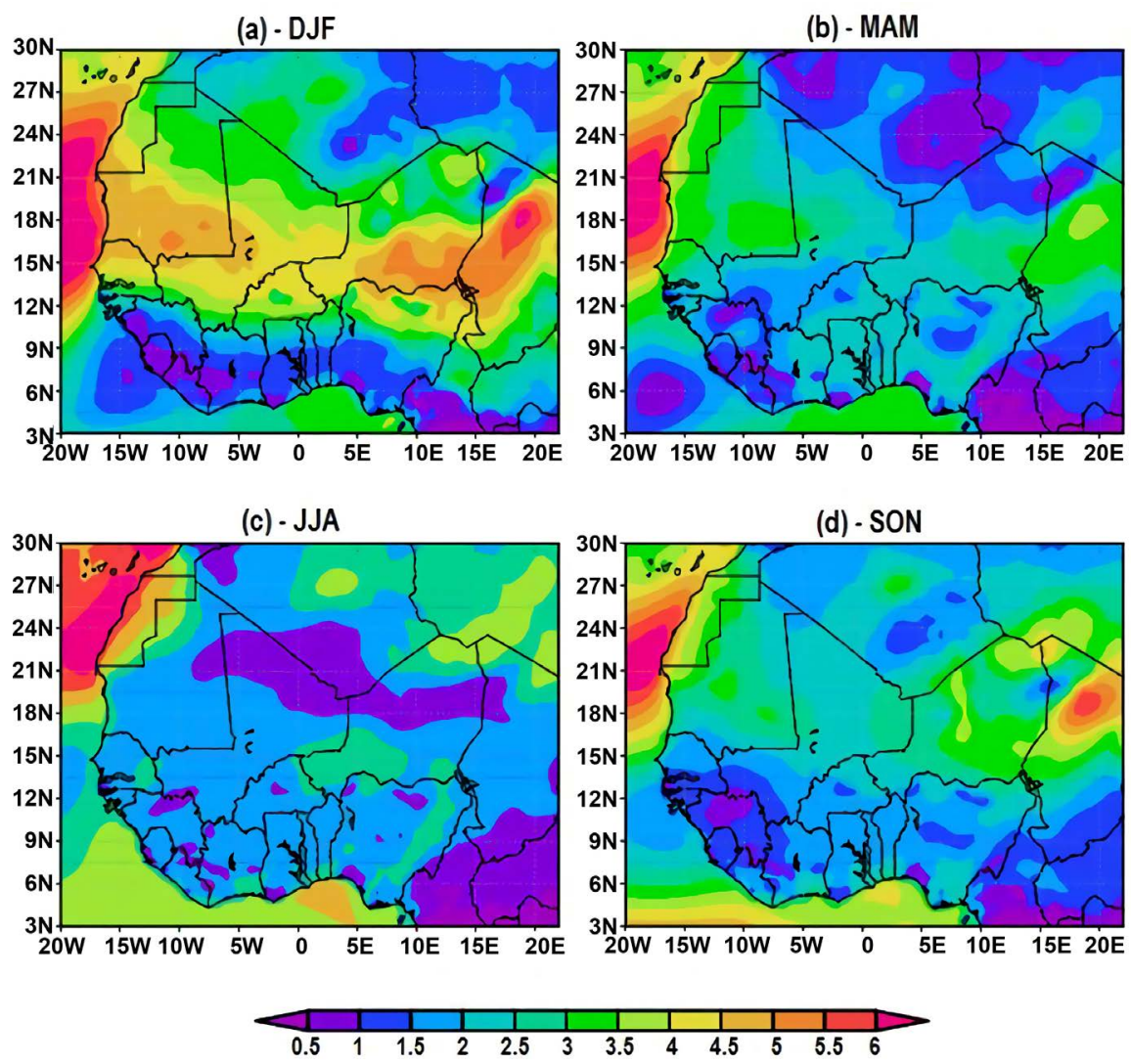

Figure 5. Seasonal averages of zonal and southern wind speed at $10 \mathrm{~m}$ altitude over West Africa between December 2000 and February 2016.

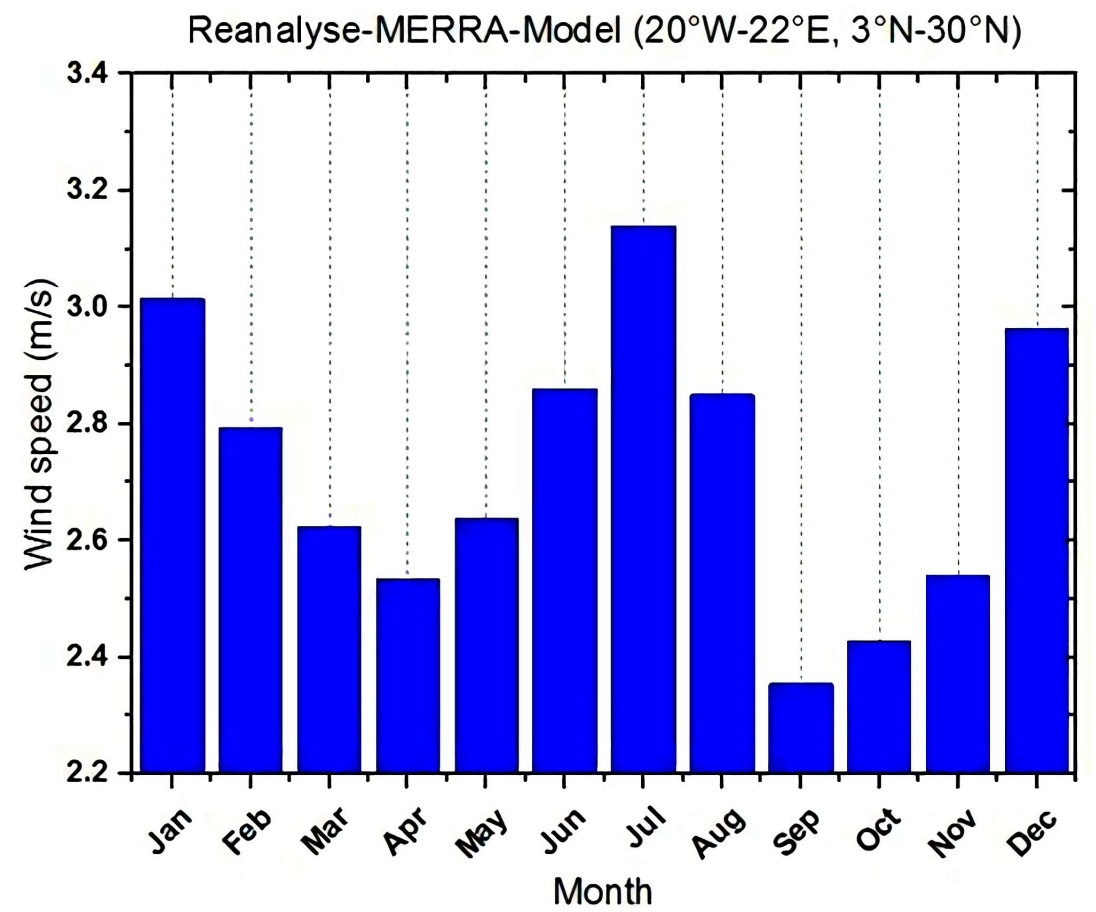

Figure 6. Histogram of the seasonal cycle of the wind speed over West Africa averaged between December 2000 and February 2016. 
On the other hand, in summer (JJA) and in agreement with Malavelle et al. [39], Drame et al. [9], the particles are more present in the Sahara in the north of the east side of Niger, the south of Algeria and northwestern Mali, particularly in the areas where desert dust is present (Figure 4(c)). In summer (JJA), the harmattan is weak in West Africa and the area is strongly influenced by southwesterly winds. However, the maxima of harmattan are rather observed towards the south of Algeria and towards Libya around $25^{\circ} \mathrm{N}$ (Figure 5(c)) being able to cause the distant transport of the desert dust in the layer of Saharan air. Note also that the wind maxima in summer (Figure 6) can be related to the monsoon flow which is preponderant and very strong during this period because of the displacement of the inter-tropical front around $20^{\circ} \mathrm{N}$ especially in July-August [40]. In this same period, the importance of the convective systems associated with the presence of the Inter-tropical Convergence Zone (ITCZ) north of the equator in the Sahel, could justify the strong dust impulses in June-July-August (JJA). Moreover, the effect of dust in the summer period is less felt in the lower layer due to atmospheric leaching by rainfall and soil moisture, but these mineral particles are much higher in the upper troposphere [10] [41].

Autumn (SON) is characterized by large particle emissions in the Sahara towards eastern Niger due to the activation of Bodélé in Chad with sources from northwestern of Mali and eastern of Mauritania (Figure 4(d)). Moreover, the autumn is marked by the transition between the harmattan and the monsoon followed by a migration of the ITCZ towards the south. This displacement is often accompanied by very violent convective systems which cause emissions of mineral dust during this period [34] [41] [42]. The importance of these systems is clearly visible by the wind maxima on the eastern side of Niger (Figure 5(d)). Furthermore, from the autumn period, solar insolation starts to decrease in the north and this is causing a lack of energy needed to maintain the monsoon causing its weakening [43]. As a result, the ITCZ and the associated atmospheric circulation are progressively withdrawing, justifying at the same time the minima of the autumn wind speeds observed in Figure 6. During winter (DJF), particles maxima are mostly observed on the southern side, probably due to combustion particles (Figure 4(a)) because of the strong activation of biomass combustion sources at this time in the Gulf of Guinea. These particles from combustion are then transported by southwest winds of Guinea area to the rest of the West African region and then mixed with desert dust [44] [45]. These mineral aerosols are related to the northeasterly harmattan flow whose maxima are observed between $10^{\circ} \mathrm{N}$ and $25^{\circ} \mathrm{N}$ (Figure $5(\mathrm{a})$ ). The importance of the northeastern trade winds in winter is also visible in Figure 6 which represents the interannual temporal evolution of the wind speed in the longitudinal zone from $20^{\circ} \mathrm{W}$ to $22^{\circ} \mathrm{E}$ and from latitude between $3^{\circ} \mathrm{N}$ and $30^{\circ} \mathrm{N}$. Also, the January-February-March (JFM) is defined as the lowest layer period of dust on the African continent where the northerly winds and northeast (harmattan) earn much more in speed quickly [46]. This is at the origin of a significant transport of dust from the Sahara to West Africa contributing to the strong values of the 
aerosol optical depth. As a result, JFM is the period of low-level dust, during which populations are more exposed to significant health risks, such as the major epidemics of bacterial meningitis [47].

\subsection{Temporal Variability of Aerosols on Different Sites in the Sahel}

Figure 7 shows the aerosol optical depth (AOD) time series of AERONET network, MODIS and SeaWiFS at $550 \mathrm{~nm}$ over different measurement periods, depending on the availability of data on the site between 2001 and 2016. This allows to see in addition to the inter-comparison made on the basis of the linear regression, a good correspondence between MODIS and AERONET notably on Banizoumbou, Cinzana and Ouagadougou, then also between SeaWiFS and AERONET for the site of Dakar. Indeed, MODIS and AERONET reproduce the maxima of AOD at the same time in spring (MAM) mainly in March for the case
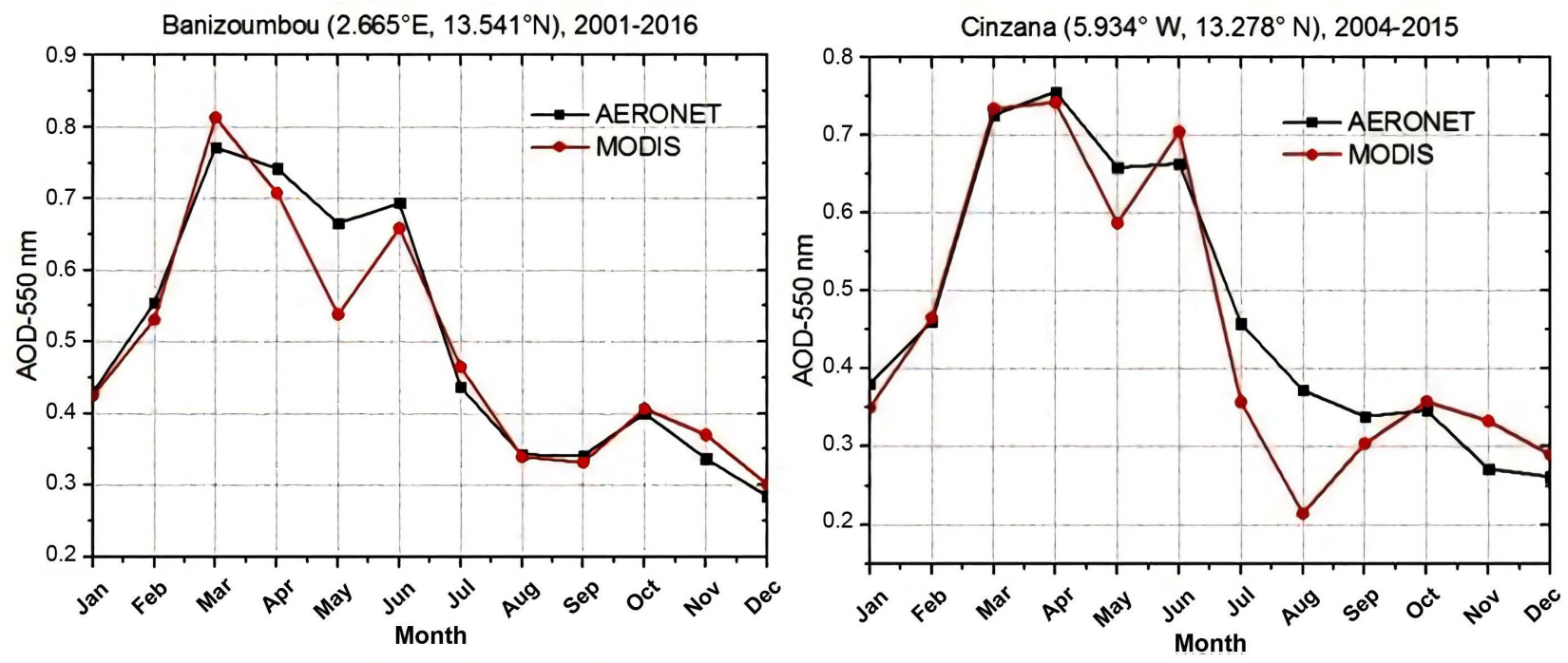

Dakar (16.959 $\left.\mathrm{W}, 14.394^{\circ} \mathrm{N}\right), 2003-2010$
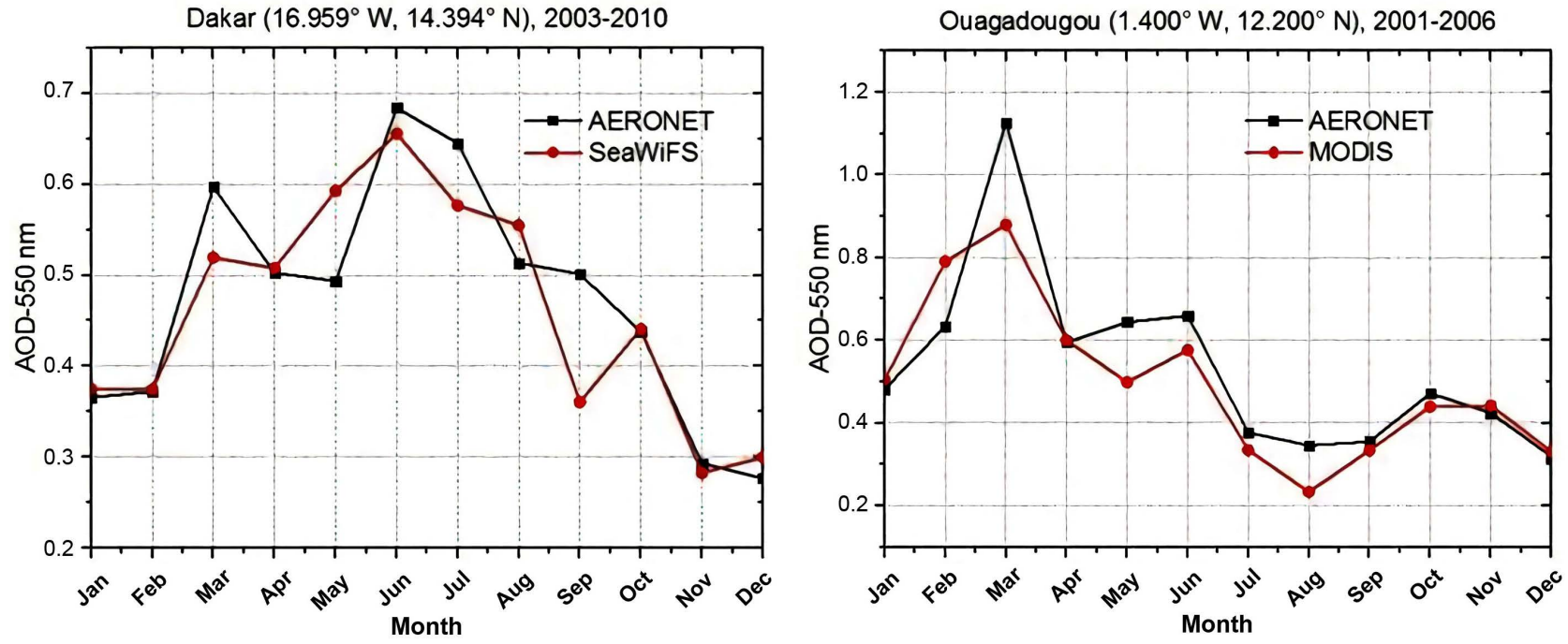

Figure 7. Seasonal cycle of aerosol optical depth (AOD) averaged between 2001-2016 at Banizoumbou, 2004-2015 at Cinzana, 2003-2010 at Dakar and 2001-2006 at Ouagadougou of the AERONET network and airborne sensors (MODIS and SeaWiFS). 
of Banizoumbou and Ouagadougou then in April for Cinzana. This representation (Figure 7) is consistent with the seasonality of aerosols in West Africa shown in Figure 4 and controlled by climate dynamics. Also, the AOD maxima observed in spring at some sites such as Banizoumbou and Cinzana may be related to their proximity to emission sources making them victims of short-range transport [16] [48]. The AOD peaks observed in summer in June and autumn in October are probably due to the convective systems at the beginning and end of the rainy season respectively in June and October related to the installation and recession of the monsoon.

In order to better understand the seasonality of the aerosol size class, a coupled analysis between the aerosol optical depth (AOD)and the Angström coefficient at (440 - 870) $\mathrm{nm}$ is made and concerns the four sites (Figure 8). This representation shows a dominance of large size particles associated with desert dust
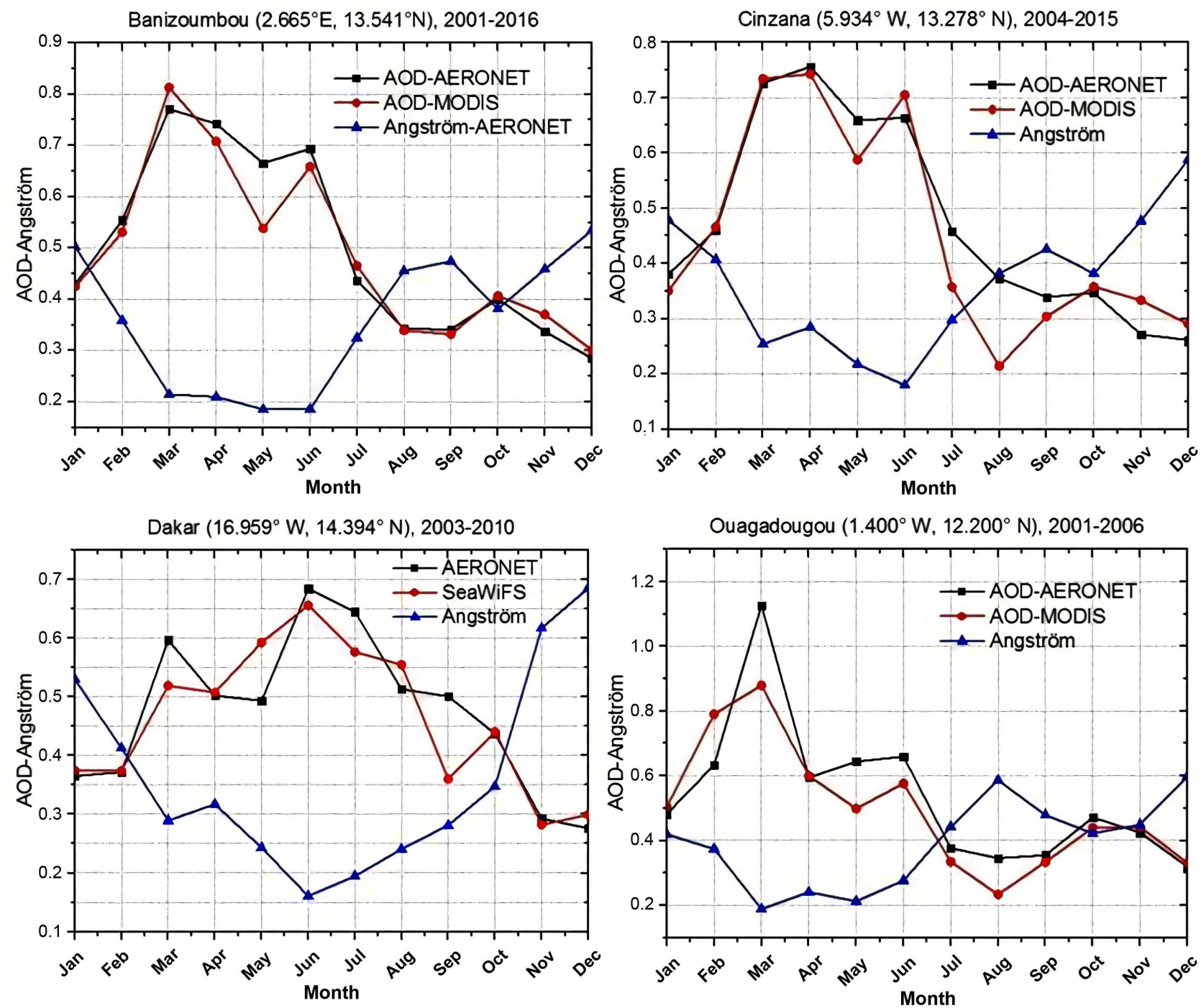

Figure 8. Seasonal cycle of aerosol optical depth (AOD) and the Angström coefficient averaged between 2001-2016 at Banizoumbou, 2004-2015 at Cinzana, 2003-2010 at Dakar and 2001-2006 at Ouagadougou of the AERONET network and airborne sensors (MODIS and SeaWiFS). 
on all sites especially in spring and early summer in June. These desert aerosols are indeed confirmed by the low values of the Angström coefficient $\left(\alpha_{440-870}<0.3\right)$ calculated in these periods with minima recorded in March and May around 0.18 at the sites of Ouagadougou and Banizoumbou. These same minimum values are noted in June at the sites of Cinzana and Dakar respectively around 0.17 and 0.16 . This signature of the desert dust between March and June is corroborated by Dramé et al. [9] which in agreement with Mcconnell et al. [49] associates at this same period single scattering albedo (SSA) values higher than 0.9 [1]. This shows the scattering character of particle in the Sahel thus confirming their nature and primary origin (mineral dust) with a small contribution of more absorbing combustion particles. However, the values of the Angström coefficient observed between the months of July, August and September are probably due to the fine desert particles from long-range transport at medium and high troposphere as well as local combustion particles [41]. Moreover, during autumn and winter, sources of combustion are active in the Gulf of Guinea with a high intensity in winter. This generates combustion particles that are then transported by winds from the southwest to the rest of the continent. Following this, the maxima of the Angström coefficient observed in winter, particularly at the Banizoumbou, Cinzana, Dakar and Ouagadougou sites, show the state of mixing of the aerosol layer at this time in the Sahel. This layer of aerosols is in fact made up of fine desert particles linked to northeasterly winds and combustion in agreement with the intense activation of bush fires in the Gulf of Guinea [50].

\section{Conclusion}

This work is an optical and microphysical characterization of aerosols in the West African zone on the basis of measurements of MODIS, SeaWiFS sensors and in situ measurements of the AERONET network, then reanalysis of the MERRA model between 2001 and 2016. This is of paramount importance for a better understanding of the exact role of aerosols in the climate system. For this purpose, a validation of the satellite measurements shows a very good representation of the MODIS sensor with relatively high correlation coefficients $\mathrm{R}$ on the sites of Banizoumbou, Cinzana and Dakar. However, SeaWiFS is less representative on the Ouagadougou site while MODIS shows a poor correlation on the Dakar site. Also, the combined analysis of satellite observations and AERONET data makes it possible to locate the aerosol period in the Sahel in spring and summer in agreement with aerosol climatology in the sub-region justified by the atmospheric dynamics. However, these particles are strongly influenced by desert dust whose main sources are located in the north of the continent.

\section{Acknowledgements}

We thank Didier, the principal investigator of AERONET sites for the availability of AERONET data and NASA (National Aeronautics and Space Administration) for earth observations. The ISP, Uppsala University, Sweden is gratefully acknowledged for their support to project BUF01. 


\section{Conflicts of Interest}

The authors declare no conflicts of interest regarding the publication of this paper.

\section{References}

[1] Nébon, B., Dramé, M.S., Bruno, K., Florent, K.P., Sall, S.M. and Joseph, D. (2018) Optical and Microphysical Analysis of Aerosols in Sahelian Zone: Case of the Ouagadougou City in Burkina Faso. Elixir International Journal, 119, 50975-50982.

[2] Drame, M.S., Ceamanos, X., Roujean, J.L., Boone, A., Lafore, J.P., Carrer, D. and Geoffroy, O. (2015) On the Importance of Aerosol Composition for Estimating Incoming Solar Radiation: Focus on the Western African Stations of Dakar and Niamey during the Dry Season. Atmosphere (Basel), 6, 1608-1632. https://doi.org/10.3390/atmos6111608

[3] Woodward, S. (2001) Modeling the Atmospheric Life Cycle and Radiative Impact of Mineral Dust in the Hadley Centre Climate Mode. Journal of Geophysical Research, 106, 18155-18166. https://doi.org/10.1029/2000JD900795

[4] D’Almeida, G.A. (1986) A Model for Saharan Dust Transport. American Meteorological Society, 25, 903-916. https://doi.org/10.1175/1520-0450(1986)025<0903:AMFSDT>2.0.CO;2

[5] Drame, M., Jenkins, G.S., Camara, M. and Robjhon, M. (2011) Observations and Simulation of a Saharan Air Layer Event with a Midtropospheric Dust Layer at Dakar, Senegal, 6-7 July 2010. Journal of Geophysical Research, 116, 6-7. https://doi.org/10.1029/2011JD016368

[6] Huang, J., Minnis, P., Yan, H., Yi, Y., Chen, B., Zhang, L. and Ayers, J.K. (2010) Dust Aerosol Effect on Semi-Arid Climate over Northwest China Detected from A-Train Satellite Measurements. Atmospheric Chemistry and Physics, 10, 6863-6872. https://doi.org/10.5194/acp-10-6863-2010

[7] Prospero, J.M., Ginoux, P., Torres, O., Nicholson, S.E. and Gill, T.E. (2002) Environmental Characterization of Global Sources of Atmospheric Soil Dust Identified with the Nimbus 7 Total Ozone Mapping Spectrometer (TOMS) Absorbing Aerosol Product. Reviews of Geophysics, 40, 1-31. https://doi.org/10.1029/2000RG000095

[8] Li, Z., Xia, X., Cribb, M., Mi, W., Holben, B., Wang, P., Chen, H., Tsay, S., Eck, T.F., Zhao, F., Dutton, E.G. and Dickerson, R.E. (2008) Aerosol Optical Properties and Their Radiative Effects in Northern China. Journal of Geophysical Research, 112, D22S01. https://doi.org/10.1029/2006JD007382

[9] Drame, M.S., Camara, M. and Gaye, A.T. (2013) Intra-Seasonal Variability of Aerosols and Their Radiative Impacts on Sahel Climate during the Period 2000-2010 Using AERONET Data. International Journal of Geosciences, 4, 267-273. https://doi.org/10.4236/ijg.2013.41A024

[10] Senghor, H., Machu, É., Hourdin, F. and Gaye, A.T. (2017) Seasonal Cycle of Desert Aerosols in Western Africa: Analysis of the Coastal Transition with Passive and Active Sensors. Atmospheric Chemistry and Physics, 17, 8395-8410. https://doi.org/10.5194/acp-17-8395-2017

[11] Delfino, R.J., Sioutas, C. and Malik, S. (2005) Review Potential Role of Ultrafine Particles in Associations between Airborne Particle Mass and Cardiovascular Health. Environmental Health Perspectives, 113, 934-946. https://doi.org/10.1289/ehp.7938

[12] Donaldson, K., Stone, V., Seaton, A. and Macnee, W. (2001) Ambient Particle Inha- 
lation and the Cardiovascular System: Potential Mechanisms. Environmental Health Perspectives, 109, 523-527. https://doi.org/10.2307/3454663

[13] Sultan, B., Labadi, K., Guégan, J.-F. and Janicot, S. (2005) Climate Drives the Meningitis Epidemics Onset in West Africa. PLOS Medicine, 2, 43-49.

https://doi.org/10.1371/journal.pmed.0020006

[14] Diokhane, A.M., Jenkins, G.S., Manga, N. and Drame, M.S. (2015) Linkages between Observed, Modeled Saharan Dust Loading and Meningitis in Senegal during 2012 and 2013. International Journal of Biometeorology, 60, 557-575. https://doi.org/10.1007/s00484-015-1051-5

[15] Korgo, B. (2014) Caractérisation optique et microphysique des aérosols atmosphériques en zone urbaine ouest africaine: Application aux calculs du forçage radiatif à Ouagadougou. PhD Thesis, Universite de Ouagadougou, Ouagadougou.

[16] Drame, M.S. (2012) Caractérisation et impacts climatiques des aérosols en Afrique de l'ouest. PhD Thesis, Université Cheick Anta DIOP de Dakar, Dakar.

[17] Holben, B.N., Eck, T.F., Slutsker, I., Tanre, D., Buis, J.P., Setzer, A., Vermote, E., Reagan, J.A., Kaufman, Y.J., Nakajima, T., Lavenu, F., Jankowiak, I. and Smirnov, A. (1998) AERONET - A Federated Instrument Network and Data Archive for Aerosol Characterization. Remote Sensing of Environment, 66, 1-16. https://doi.org/10.1016/S0034-4257(98)00031-5

[18] Dubovik, O. and King, D. (2000) A Flexible Inversion Algorithm for Retrieval of Aerosol Optical Properties from Sun and Sky Radiance Measurements. Journal of Geophysical Research, 105, 20673-20696. https://doi.org/10.1029/2000JD900282

[19] Dubovik, O., Smirnov, A., Holben, B.N., King, M.D., Kaufman, Y.J., Eck, T.F. and Slutske, I. (2000) Accuracy Assessments of Aerosol Optical Properties Retrieved from Aerosol Robotic Network (AERONET) Sun and Sky Radiance Measurements. Journal of Geophysical Research, 105, 9791-9806. https://doi.org/10.1029/2000JD900040

[20] Dubovik, O. (2004) Optimization of Numerical Inversion in Photopolarimetric Remote Sensing. In: Videen, G., Yatskiv, Y. and Mishchenko, M., Eds., Photopolarimetry in Remote Sensing, Springer, Berlin, Vol. 161, 65-106. https://doi.org/10.1007/1-4020-2368-5_3

[21] Dubovik, O., Holben, B.N., Lapyonok, T., Sinyuk, A., Mishchenko, M.I., Yang, P. and Slutsker, I. (2002) Non-Spherical Aerosol Retrieval Method Employing Light Scattering by Spheroids. Geophysical Research Letters, 29, 54-1-54-4. https://doi.org/10.1029/2001GL014506

[22] Diarra, C. and Ba, A. (2014) Analyse des paramètres optiques des aérosols atmosphériques, de leur distribution et de leur albédo de diffusion par les mesures photométriques au Mali. Afrique Science, 10, 82-97.

[23] Levy, R.C., Remer, L.A., Mattoo, S., Vermote, E.F. and Kaufman, Y.J. (2007) Second-Generation Operational Algorithm: Retrieval of Aerosol Properties over Land from Inversion of Moderate Resolution Imaging Spectroradiometer Spectral Reflectance. Journal of Geophysical Research, 112, D13211. https://doi.org/10.1029/2006JD007811

[24] Kaufman, Y.J., Tanr, D., Remer, L.A., Vermote, E.F. and Chu, A. (1997) Operational Remote Sensing of Tropospheric Aerosol over Land from EOS Moderate Resolution Imaging Spectroradiometer. Journal of Geophysical Research, 102, 17051-17067. https://doi.org/10.1029/96JD03988

[25] Tanré, D., Kaufman, Y.J., Herman, M. and Mattoo, S. (1997) Remote Sensing of Aerosol Properties over Oceans Using the MODIS/EOS Spectral Radiances. Journal of Geophysical Research, 102, 16971-16988. https://doi.org/10.1029/96JD03437 
[26] Remer, L.A., Kaufman, Y.J., Tanré, D., Mattoo, S., Chu, D.A., Martins, J.V., Li, R.R., Ichoku, C., Levy, R.C., Kleidman, R.G., Eck, T.F., Vermote, E. and Holben, B.N. (2005) The MODIS Aerosol Algorithm, Products, and Validation. American Meteorological Society, 62, 947-973. https://doi.org/10.1175/JAS3385.1

[27] Hsu, N.C., Tsay, S., King, M.D., Member, S. and Herman, J.R. (2004) Aerosol Properties over Bright-Reflecting Source Regions. IEEE Transactions on Geoscience and Remote Sensing, 42, 557-569. https://doi.org/10.1109/TGRS.2004.824067

[28] Myhre, G., Stordal, F., Johnsrud, M., Diner, D.J., Geogdzhayev, I.V., Holben, B., Ignatov, A., Kahn, R., Myhre, G., Stordal, F., Johnsrud, M., Diner, D.J. and Geogdzhayev, I.V. (2004) Intercomparison of Satellite Retrieved Aerosol Optical Depth over Ocean during the Period September 1997 to December 2000. Atmospheric Chemistry and Physics, Discussions, 4, 8201-8244. https://doi.org/10.5194/acpd-4-8201-2004

[29] Wang, M., Knobelspiesse, K.D. and Mcclain, C.R. (2005) Study of the Sea-Viewing Wide Field-of-View Sensor (SeaWiFS) Aerosol Optical Property Data over Ocean in Combination with the Ocean Color Products. Journal of Geophysical Research, 110, 1-14. https://doi.org/10.1029/2004JD004950

[30] Prasad, A.K., Singh, S., Chauhan, S.S., Srivastava, M.K., Singh, R.P. and Singh, R. (2007) Aerosol Radiative Forcing over the Indo-Gangetic Plains during Major Dust Storms. Atmospheric Environment, 41, 6289-6301. https://doi.org/10.1016/j.atmosenv.2007.03.060

[31] Liu, J., Zheng, Y., Li, Z. and Wu, R. (2008) Ground-Based Remote Sensing of Aerosol Optical Properties in Once City in Northwest China. Atmospheric Research, 89, 194-205. https://doi.org/10.1016/j.atmosres.2008.01.010

[32] Alam, K., Qureshi, S. and Blaschke, T. (2011) Monitoring Spatio-Temporal Aerosol Patterns over Pakistan Based on MODIS, TOMS and MISR Satellite Data and a HYSPLIT Model. Atmospheric Environment, 45, 4641-4651.

https://doi.org/10.1016/j.atmosenv.2011.05.055

[33] Kumar, K.R., Yin, Y., Sivakumar, V., Kang, N., Yu, X., Diao, Y., Adesina, J. and Reddy, R.R. (2015) Aerosol Climatology and Discrimination of Aerosol Types Retrieved from MODIS, MISR and OMI over Durban $\left(29.88^{\circ} \mathrm{S}, 31.02^{\circ} \mathrm{E}\right)$, South Africa. Atmospheric Environment, 117, 9-18. https://doi.org/10.1016/j.atmosenv.2015.06.058

[34] Bibi, H., Alam, K., Chishtie, F., Bibi, S., Shahid, I. and Blaschke, T. (2015) Intercomparison of MODIS, MISR, OMI, and CALIPSO Aerosol Optical Depth Retrievals for Four Locations on the Indo-Gangetic Plains and Validation against AERONET Data. Atmospheric Environment, 111, 113-126. https://doi.org/10.1016/j.atmosenv.2015.04.013

[35] Ichoku, C., Chu, D.A., Mattoo, S., Kaufman, Y.J., Remer, L.A., Tanre, D., Slutsker, I. and Holben, B.N. (2002) A Spatio-Temporal Approach for Global Validation and Analysis of MODIS Aerosol Products. Geophysical Research Letters, 29, 1616. https://doi.org/10.1029/2001GL013206

[36] Reese, G.C., Wilson, K.R. and Flather, C.H. (2014) Performance of Species Richness Estimators across Assemblage Types and Survey Parameters. Global Ecology and Biogeography, 23, 585-594. https://doi.org/10.1111/geb.12144

[37] Marticorena, B., Haywood, J., Coe, H., Formenti, P., Liousse, C., Mallet, M. and Pelon, J. (2011) Tropospheric Aerosols over West Africa: Highlights from the AMMA International Program. Atmospheric Science Letters, 12, 19-23. https://doi.org/10.1002/asl.322

[38] Malavelle, F. (2011) Effets direct et semi-direct des aérosols en Afrique de l'ouest pendant la saison sèche. PhD Thesis, Université Toulouse III Paul Sabatier (UT3 
Paul Sabatier).

[39] Malavelle, F., Mallet, M., Pont, V., Liousse, C. and Solmon, F. (2011) Long-Term Simulations (2001-2006) of Biomass Burning and Mineral Dust Optical Properties over West Africa: Comparisons with New Satellite Retrievals. Atmospheric Chemistry and Physics, Discussions, 11, 28587-28626. https://doi.org/10.5194/acpd-11-28587-2011

[40] Sultan, B., Janicot, S. and Drobinski, P. (2007) Characterization of the Diurnal Cycle of the West African Monsoon around the Monsoon Onset. Journal of Climate, 20, 4014-4032. https://doi.org/10.1175/JCLI4218.1

[41] Korgo, B., Roger, J. and Bathiebo, J. (2013) Climatology of Air Mass Trajectories and Aerosol Optical Thickness over Ouagadougou. Global Journal of Pure and Applied Sciences, 19, 169-181.

[42] Devara, P.C.S., Saha, S.K., Raj, P.E., Sonbawne, S.M., Dani, K.K., Tiwari, K. and Maheskumar, R.S. (2005) A Four-Year Climatology of Total Column Tropical Urban Aerosol, Ozone and Water Vapor Distributions over Pune, India. Aerosol and Air Quality Research, 5, 103-114. https://doi.org/10.4209/aaqr.2005.06.0007

[43] Cécile, K. (2011) Interactions entre poussières désertiques et convection profonde en Afrique de l'Ouest: Observation et modélisation à échelle convective. $\mathrm{PhD}$ Thesis, Université de Toulouse, Toulouse.

[44] Derimian, Y., Le, J., Dubovik, O., Chiapello, I., Tanre, D., Podvin, T., Brogniez, G. and Holben, B.N. (2008) Radiative Properties of Aerosol Mixture Observed during the Dry Season 2006 over M Bour, Senegal (African Monsoon Multidisciplinary Analysis Campaign). Journal of Geophysical Research, 113, D00C09. https://doi.org/10.1029/2008JD009904

[45] Haywood, J.M., Pelon, J., Formenti, P., Bharmal, N., Brooks, M., Capes, G., Chazette, P., Chou, C., Christopher, S., Coe, H., Cuesta, J., Derimian, Y., Desboeufs, K., Greed, G., Harrison, M., Heese, B., Highwood, E.J., Johnson, B., Mallet, M., Rajot, J., Schulz, M., Slingo, A., Tanre, D. and Tulet, P. (2008) Overview of the Dust and Biomass-Burning Experiment and African Monsoon Multidisciplinary Analysis Special Observing Period-0. Journal of Geophysical Research, 113, D00C17. https://doi.org/10.1029/2008JD010077

[46] Martiny, N., Roucou, P., Pohl, B., Camberlin, P. and Chiapello, I. (2015) Définition d'un événement de poussières désertiques au sahel: Apport de nouvelles mesures de PM10 au Burkina Faso. XXVIIIe Colloque de I AssociationInternationale de Climatologie, Liège, 194-199.

[47] Martiny, N. and Chiapello, I. (2013) Assessments for the Impact of Mineral Dust on the Meningitis Incidence in West Africa. Atmospheric Environment, 70, 245-253. https://doi.org/10.1016/j.atmosenv.2013.01.016

[48] Chiapello, I., Bergametti, G., Gomes, L. and Chatenet, B. (1995) An Additional Low Layer Transport of Sahelian and Saharan Dust over the North-Eastern Tropical Atlantic. Geophysical Research Letters, 22, 3191-3194. https://doi.org/10.1029/95GL03313

[49] Mcconnell, C.L., Highwood, E.J., Coe, H., Formenti, P., Anderson, B., Osborne, S., Nava, S., Desboeufs, K., Chen, G. and Harrison, M.A.J. (2008) Seasonal Variations of the Physical and Optical Characteristics of Saharan Dust: Results from the Dust Outflow and Deposition to the Ocean (DODO) Experiment. Journal of Geophysical Research, 113, D14S05. https://doi.org/10.1029/2007JD009606

[50] Johnson, B.T., Osborne, S.R., Haywood, J.M. and Harrison, M.A.J. (2008) Aircraft Measurements of Biomass Burning Aerosol over West Africa during DABEX. Journal of Geophysical Research, 113, D00C06. https://doi.org/10.1029/2007JD009451 